\title{
Land Evaluation in terms of Agroforestry Suitability, an Approach to Improve Livelihood and Reduce Poverty: A FAO based Methodology by Geospatial Solution: A case study of Palamu district, Jharkhand, India
}

\author{
Firoz Ahmad, Laxmi Goparaju*
}

Vindhyan Ecology and Natural History Foundation, Mirzapur, Uttar Pradesh, India; Vindhya Bachao Secretariat, 36/30, Shivpuri Colony, Station Road, Mirzapur-231001, Uttar Pradesh, India, *e-mail: goparajulaxmi@yahoo.com

Received: 26 April 2017/Accepted: 02 June 2017

\begin{abstract}
Agroforestry has enormous potential for reducing the poverty, enhancing the livelihood, improving the food security and mitigating the climate change. The agroforestry suitability mapping is performed using remote sensing and GIS technology based on a similar guideline issued by FAO for Land suitability mapping.

The study aims at applying the geospatial tools to various soil and environmental data in the Palamu district of Jharkhand, India, to achieve a nutrient availability and agroforestry suitability map in the open area. The Landsat satellite data, ASTER DEM and decadal annual rainfall data were used to generate wetness, land use/land cover (LULC), elevation, slope, and rainfall maps. The LULC map was used to identify/mask the open land where agroforestry suitability was evaluated. Various layers such as soil nitrogen (N), phosphorus $(\mathrm{P})$, potassium $(\mathrm{K})$, organic carbon $(\mathrm{C})$, $\mathrm{pH}$ and sulphur $(\mathrm{S})$ were used to generate a nutrient availability map. The agroforestry suitability surface was generated using the layers viz. nutrient availability, slope, wetness, rainfall and elevation through GIS integration in the ArcGIS 10.1 platform by assigning different weights to each thematic layer as per its importance. The thematic layer weight was calculated based on statistical analysis (pairwise comparisons). Finally, agroforestry suitability maps were generated in the form of high, medium and low grids with $1 \mathrm{~km} \mathrm{x} 1 \mathrm{~km}$ spacing. We also generated a poverty map, a map for one of the complete watersheds covering a specific part of the study area and a drainage map for the whole study area to understand its relationship/ proximity to a high agroforestry suitability grid.

A total of 3334 open-area grids were identified, $62 \%$ of which were found to be highly suitable for agroforestry. Furthermore, watersheds, drainage and poverty maps were evaluated based on its proximity to agroforestry suitability. The study reveals that the proximity of the high agroforestry suitability land grid towards the high poverty grid was approximately more than $80 \%$, whereas the proximity to the drainage pattern was roughly $70 \%$. Evaluation of the complete watershed covering part of the study area reveals that approximately $60 \%$ of the watershed area grid has the proximity of a high agroforestry suitable land grid.

The high agroforestry suitability and its proximity to high poverty, drainage pattern and watershed-based analysis offer opportunities for local people to use agroforestry in soil and water conservation practices, provided they are supported by adequate funds and technology, and will greatly contribute to poverty alleviation and an increase of the livelihood. The ongoing agroforestry projects can be further extended in open areas of a high agroforestry suitability grid for long-term benefits.

The research findings are of great importance as the majority of people in rural areas in India suffer from poverty and too small livelihood. Therefore, India has adopted the agroforestry policy that exploits its potential. The government needs to extend and implement agroforestry projects accordingly. There is an urgent need to assess and analyse such problems and to generate a village-to-state map to better understand the potential of land for agroforestry, which would strengthen the efforts of policy makers to create better and sustainable future.
\end{abstract}

Key words: Agroforestry suitability; FAO; Jharkhand, Palamu; Nutrient availability; GIS and Remote sensing. 


\section{Introduction}

Agroforestry is defined by International Council for Research in Agroforestry (ICRAF) as "integration can be either spatial mixture or temporal sequence on land-use systems and practices where woody perennials are deliberately integrated with crops and/or animals on the same land management unit". Multifunctional and traditional resource management practice such as agroforestry Systems has the potential on land-use options that enhance livelihood security through simultaneous production of food, fodder and firewood and reduce vulnerability to climate and environmental change (Pandey, 2005).

In the year 1976 FAO (http://www.fao.org/docrep/ t0715e/t0715e 06.htm) has suggested methods to evaluate the suitability of land. Land evaluation is defined as "the study of land performance/ capability when utilized for a specified purpose, this includes the execution and interpretation of surveys and analysis of land forms, soils, vegetation, climate and other characteristics of land in order to recognize and make a comparison of promising kinds of land use in terms of its suitability to the objectives of the evaluation" (FAO, 1976).

Many countries have adopted agroforestry system because of its economic, social, and ecological benefits (Watson et al., 2000). Various research has shown agroforestry contribution towards farm productivity and incomes (Verchot et al., 2007; Garrity, 2006) on the farms/lands by growing high value of tree species (Mbow et al., 2014), improves the soil and land fertility (Sileshi et al., 2008; Albrecht \& Kandji, 2003), provide livelihood to weaker section (Pandey, 2005) boost household resilience (Mbow et al., 2014), mitigate the impacts of climate change (Schoeneberger et al., 2012; Thorlakson et al., 2012; Nguyen et al., 2013), conserving and safeguarding biodiversity (McNeely, 2004; Jose, 2012) and improving and ameliorating air and water quality (Anderson et al., 2009; Hernandez et al., 2012; Asbjornsen et al., 2014). The agroforestry gains high importance because it provide enormous and diversified benefits as well as has the capacity to safeguard the food security for the future generation thus the world scientists gathered together in the year 2004 in Florida, USA in $1^{\text {st }}$ world congress of agroforestry chaired by one of the leading scientist P. K. Nair to discuss agenda related to agroforestry (Working Together for Sustainable Land Use Systems) (http://conference.ifas.ufl.edu/WCA/ Abstracts2.pdf).

In India, around $80 \%$ of the population living in the rural area majority of them practice agriculture for their livelihood which mostly depends on the monsoon. The climate change has altered the rainfall pattern and an increase in the severity and frequency of extreme weather events (Alley et al., 2007). In such situation the production of agriculture outputs have been put on risk thus agroforestry practice is the most viable solution to meet the challenges of food, nutrition, energy, livelihood and environmental security. Seeing its importance and potentiality to achieve sustainable growth, India grabbed the opportunity and became the first country in the world to adopt an agroforestry policy in the year 2014 (http://iksa.in/gs3/india-nationalagroforestry-policy/860/).

Jharkhand by its name means "land of forest" has an old tradition to the practice of agroforestry system ( Quli, 2001) is the land rich in mineral resources and poor in agricultural production (Singh et al., 2012) dominated by tribal, backward and weaker section of the population. Poverty in this state is among the highest in the country (World Bank, 2016). About a two-third of the districts of Jharkhand with more than $50 \%$ to $80 \%$ of the poor population (Singh et al., 2012) struggling for their livelihood and food. Palamu is among the poorest district, located in the western part of the state of Jharkhand is also one of the drought prone districts. Agriculture is the main occupation here which exhibits low productivity whereas it falls under the rain shadow part thus comes under unsure rainfall zone (http://www.jsdmd.in/pdf/Plan_Palamu.pdf). Several starvation deaths have been reported from time to time from this district (Das, 2005) whereas one of the leading newspaper of India "The Hindu" also reported the same in the year 2002 (http://www.thehindu.com/2002/07/11/ stories/2002071103831200.htm). Thus in such situation there is an urgent need to harness agroforestry practices intensively seeing its potentiality to reduce poverty $(\mathrm{Mb}$ wambo et al., 2013) by enhancing livelihood and house hold income. Furthermore, agroforestry has the capacity to achieve sustainable growth in the agriculture sector by optimizing the productivity along with diminishing climate change impacts (National Agroforestry Policy, 2014).

The advancement in Remote sensing and GIS with free data sets availability online carved the path and became a boon in the mapping technology in recent years. It has been widely used to map and monitor vegetation, urban sprawl (Ahmad \& Goparaju, 2016a), natural resource (Ahmad et al., 2017a), urban forest suitability (Ahmad \& Goparaju, 2016b), model city mapping and predictions (Ahmad et al., 2017b), mines expansion dynamic (Ahmad \& Goparaju, 2017a), malaria hotspot identification (Qayum et al., 2015; Ahmad et al., 2017c) and forest disturbance (Ahmad \& Goparaju, 2017b), but it has not been fully exploited in the field of agroforestry (Ellis et al., 2000). Very little study has been carried out based on utilizing the geospatial approach for evaluating the land suitability towards various agroforestry crops. Reisner et al. (2007) studied land suitability for part of Europe using the data soil, climate, topography, and land cover and integrated in GIS domain for identifying agroforestry target regions for few tree species (Juglans spp., Prunus avium, Popu- 
lus spp., Pinus pinea, and Quercus ilex) suitability. The study reveals Silvoarable agroforestry (SAF) systems have the potentiality to reduce the risk of soil erosion, nitrate leaching and increase landscape diversity. Ritung et al. (2007) studied land suitability of Aceh Barat District of Indonesia using climatic, soil and topographical data and evaluated land based on FAO guideline and recommended land suitability towards various agroforestry crops. Yedage et al. (2013) studied land suitability based on FAO guideline towards agroforestry fruits crop (Pomegranate) in the Sangola Tahsil of Solapur district of Maharashtra, India using multi-criteria approach and GIS application. The thematic layers used for analysis are slope, soil $\mathrm{pH}$, soil organic matter, soil NPK, soil texture, soil electric conductivity, soil depth, ground water availability and the present land use/ land cover. The study reveals roughly $27 \%$ and $18 \%$ of study area land is highly and moderately suitable respectively for pomegranate farming. Ahmad and Goparaju (2016b) evaluated land suitability towards urban forest of Ranchi city, Jharkhand, India using weighted mean approach in GIS modeling. The thematic layers used for study was wetness, slope, soil organic carbon, drainage buffer and urban buffer. They identified the potential area within the existing open space for urban forestry was $27 \%$ as highly suitable, $38 \%$ as medium suitable and $35 \%$ as least suitable sites.

The objective here is to evaluated land (open area) suitability towards agroforestry using geospatial technology. Such data is widely absent in the Indian subcontinent for agroforestry policy/decision makers, is a research gap. The study area selected was Palamu district of Jharkhand state of India because the majority of people are living in a miserable condition suffering from starvation, poverty and drought (Das, 2005) will be greatly benefited from our research findings.

The study aims for applying RS and GIS for visualizing the spatial dimension and pattern of land, soil, climate and topographical data to manifest its trends and correlation. To create a soil nutrient availability and agroforestry suitability map grid in the open area. We also generated poverty map, one of the complete watersheds in the part of the study area and drainage map in whole study area to understand its relationship/proximity toward high agroforestry suitability grid.

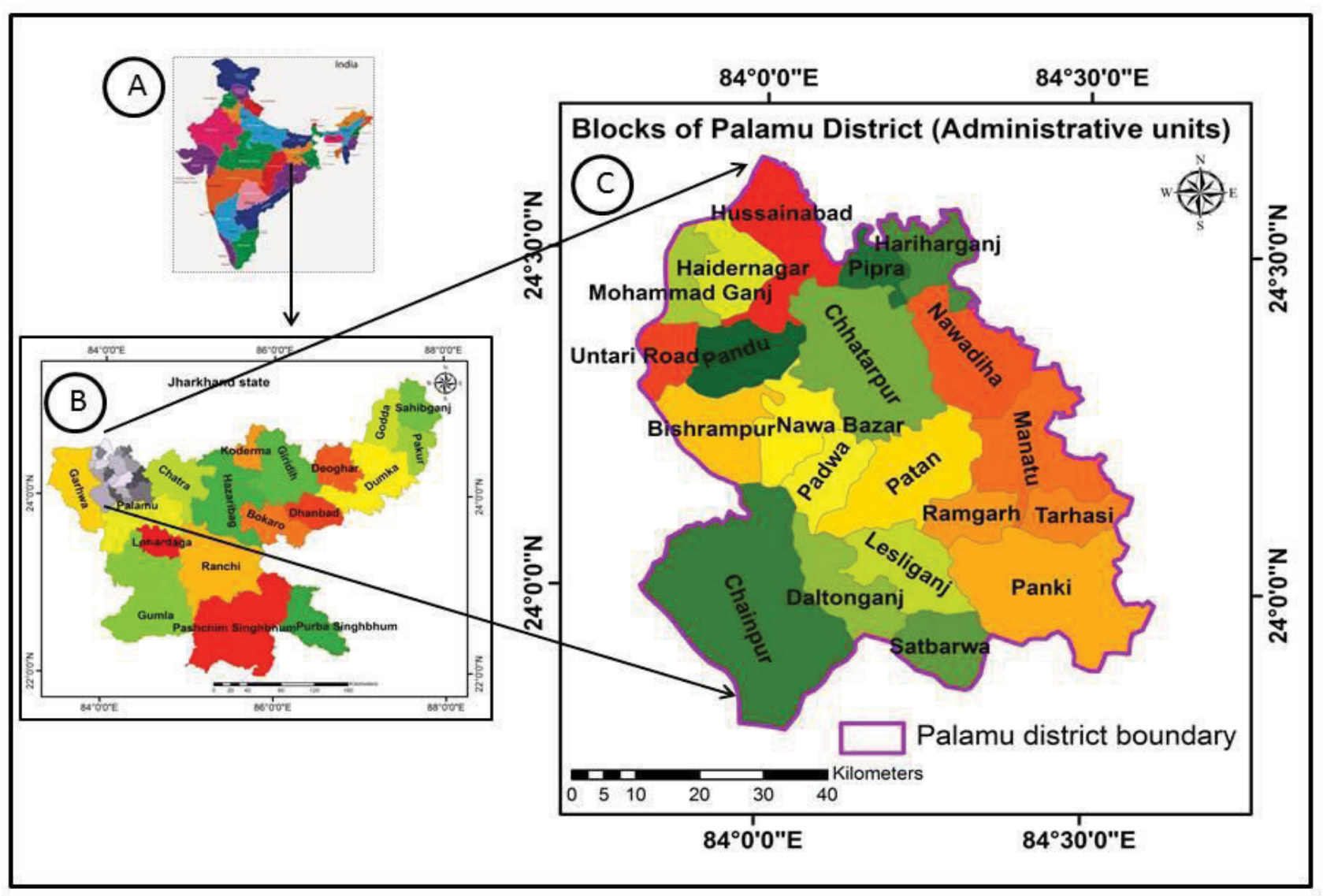

Figure 1. Study area: A - India; B - Jharkhand state; C - Palamu district 


\section{Materials and methods}

\subsection{The study area}

The geographical coordinates of the study area comprise of Latitude $23^{\circ} 47^{\prime} 39^{\prime \prime} \mathrm{N}$ to $24^{\circ} 28^{\prime} 29^{\prime}$ 'N and Longitude $83^{\circ} 48^{\prime} 18^{\prime \prime} \mathrm{E}$ to $84^{\circ} 37^{\prime} 13^{\prime}$ E, whereas total geographical area roughly is $4,586 \mathrm{~km}^{2}$ (Fig. 1). The elevation varies from 88 to $654 \mathrm{~m}$ from the mean sea level. The administrative headquarters of this district is Daltonganj. It is sur- rounded by the districts Rohtas and Aurangabad of Bihar state in north, Latehar in south, Chatra in east and Garhwa in west. Palamu district is primarily rural dominated area with the large population still residing in the villages. Agriculture practices are the main source of economy for the rural people of the district. However, agriculture is mainly for subsistence and is yet to be taken up on a commercial basis due to lack of adequate assured irrigation facility and other infrastructure bottlenecks. The decadal rainfall average varies from $944 \mathrm{~mm}$ to $1006 \mathrm{~mm}$ also coming under

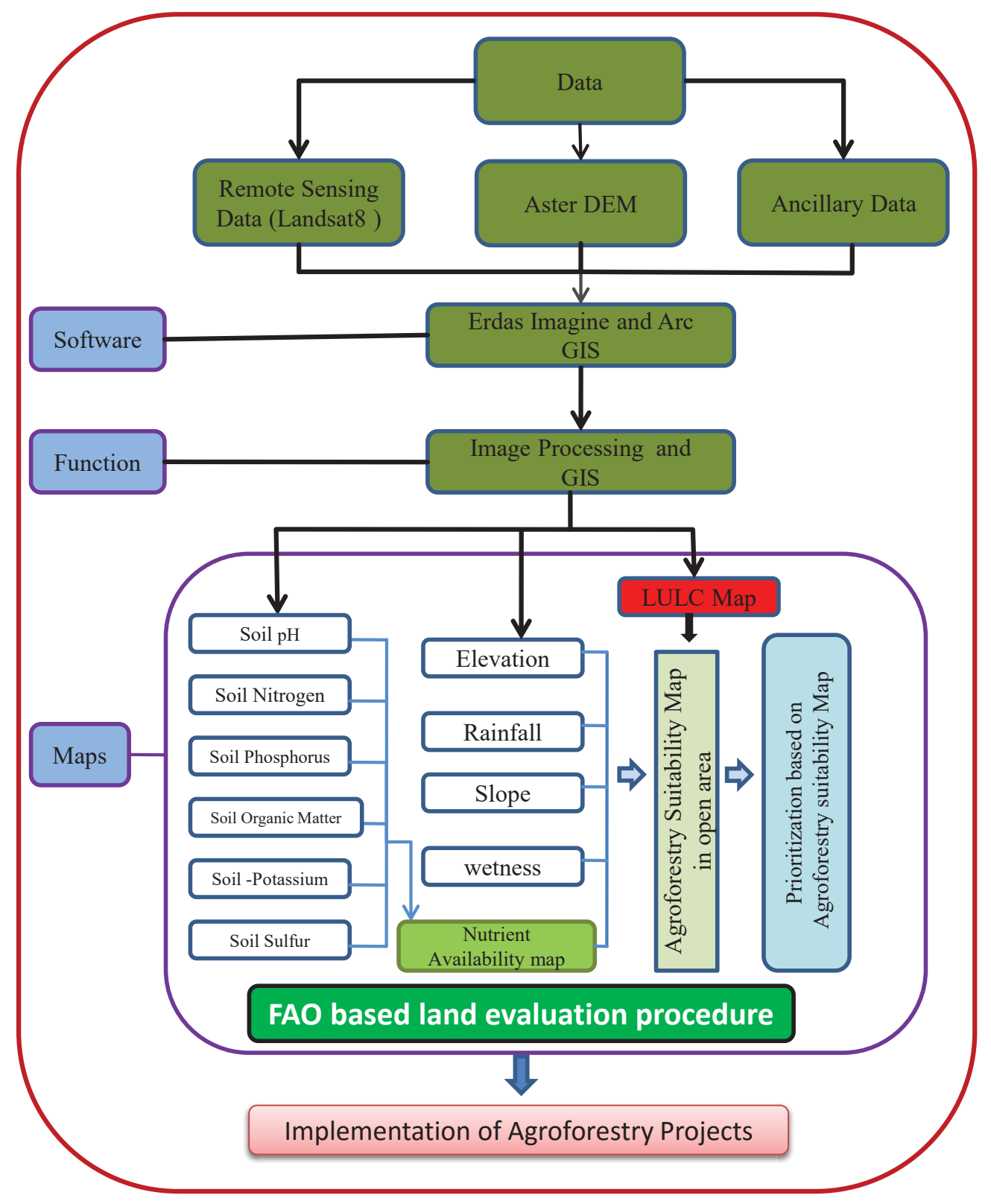

Figure 2. Flowchart for agroforestry suitability mapping 
the rain shadow part thus comes under unpredicted rainfall zone. The total population of the district as per the 1991, 2001 and 2011 census has been recorded as 1192801 , 1533173 and 1939869 respectively.

\subsection{Data preprocessing and analysis}

The satellite data (Table 1) used for the study was Landsat-8 (Path: 141/43, Row: 141/44, dated 26-12-2015) having spatial resolution $30 \mathrm{~m}$ with projection (UTMZone 45). The Landsat satellite data of the study area was downloaded from the website of United States Geological Survey (USGS). The satellite images were found free from clouds and geometrically corrected to carry out study. Various bands of the images were layer stacked to obtain a single composite image for further analysis. The scenes were mosaicked and subset was executed using the study area vector file. This subset satellite image was used to generate wetness map and land use/land cover (LULC) map for further study.

Table 1. Landsat 8 OLI data and its specification

\begin{tabular}{|c|c|c|c|}
\hline Satellite & Sensor & Path/ Row & Dates \\
\hline Landsat 8 & OLI_TIRS & $141 / 43$ & $26-12-2015$ \\
& & $141 / 44$ & $26-12-2015$ \\
\hline
\end{tabular}

ASTER DEM (30m resolution) of the study area was obtained by downloading it from the USGS website. Thematic layer such as slope and elevation were generated from study area DEM using spatial analyst tools of ArcGIS Software. Ancillary decadal rainfall data (1993-2002) was downloaded http://www.indiawaterportal.org/met_data/ (Indian Water Portal, 2016) and used to obtain rainfall map based on interpolation method. The detail of the methodology is presented in flowchart (Fig. 2).

\subsection{Generation of various thematic layers for nutrient availability mapping}

Palamu district soil map viz. nitrogen $(\mathrm{N})$, phosphorus $(\mathrm{P})$, potassium $(\mathrm{K})$, organic carbon $(\mathrm{C}), \mathrm{pH}$ and soil sulphur (S) was utilized and each map was projected, digitized and polygon id was assigned and brought in GIS domain (Fig. 3).

\subsection{Generation of various thematic layers for agroforestry suitability mapping}

\subsubsection{Digital elevation model}

Elevation is considered as an important parameter in agroforestry (Bijalwan et al., 2015) which influences the plant growth to a large extent (Franklin, 2001). As the elevation gradually increases, temperature and vegetation decreases and therefore a concept of tree line (timber line) exists. Tree doesn't grow above tree line due to less air pressure and reduced level of carbon dioxide. Carbon dioxide is important for plant metabolism and growth. The DEM was further reclassified into five sub groups at 200 meter interval and new values were re-assigned based upon the agroforestry suitability rating, were ranked as 3, 2, and 1 and described as high, medium, low, respectively (Fig. 5).

\subsubsection{Rainfall intensity}

Spatial variation of rainfall is considered as an important influential climatic parameter in crop production, its variation show positive correlation with the plant growth and used in suitability mapping (Sarkar et al., 2014). The average annual rainfall data from the year 1993 to the year 2002 (10 years) was used to generate spatial rainfall pattern (continuous surface) in ArcGIS by kriging interpolation technique. (https://www.esri.com/news/arcuser/0704/ files/interpolating.pdf). Based upon agroforestry suitability, the rainfall map was further classified into three classes $(<965,965-985,>985 \mathrm{~mm})$; were ranked as 1,2 and 3 and described as low, medium and high, respectively (Fig. 5).

\subsubsection{Slope percent}

Slope or inclination of a land defined as the measurement of the rate of change of elevation of the land per unit distance. The steepness of a slope affects plant growth (http:// www.cropsreview.com/abiotic-factors.html). The steeper slopes allow faster movement of water thus soil erosion and soil loss is more. Furthermore steeper slopes soil cannot withhold moisture for longer duration due to poor water stability. Land with gentle slopes is potential good for plant growth as water stays there for some period provides adequate moisture to the soil. Thus the gentle slopes are more favorable for agroforestry than steep slopes. The slope was derived from aster DEM and it was reclassified into classes of $<5^{\circ}, 5-15^{\circ},>15^{\circ}$ using standard reclassification technique and was ranked as 3,2 , and 1 with high, moderate and low description (Fig. 5).

\subsubsection{Wetness index}

Soil wetness is necessary for plant growth, good soil moisture improves the nutrient uptake in plant (http://broome. soil.ncsu.edu/ssc051/Lec3.htm) therefore it is an important for agroforestry practices. Baig et al. (2014) have developed a formula for generating wetness from Landsat- 8 data widely used by scientific research (Table 2). The different band coefficients were used to generate wetness map of the study area. Based upon suitability towards agroforestry, 
three classes based on the wetness values $(<-0.11,-0.11$ to $+0.11,>+0.11$ ) have been identified and were ranked as 1, 2 and 3 with description of low, medium and high, respectively (Fig. 5).

\subsubsection{LULC mapping}

The FCC image was utilized to obtain a LULC map. The supervised classification (maximum likelihood technique) was performed over the images with providing 8-10 training sets of each class distributed uniformly throughout the image. Image alarm was executed to understand, validate and finalize the training sets. All classified dataset containing four classes namely vegetation, water, settlement and open area. The open area land was evaluated for the agroforestry suitability studies was our objective of this research. The potential site in this area should be identified for further agroforestry extension and development projects.

\subsection{Agroforestry mapping parameters}

The thematic layers (Fig. 5) which is important for the growth of various agroforestry plants are nutrient availability, slope, wetness, rainfall and elevation (written in order of importance) whose weights were statistically chosen. Weights were calculated for different thematic maps were based on pairwise comparison (Table 3 and 4) introduced by Saaty et al. (1980).

Table 2. Wetness coefficients for Landsat 8 OLI reflectance

\begin{tabular}{|c|c|c|c|c|c|c|}
\hline Band & Blue & Green & Red & NIR & SWIR 1 & SWIR 2 \\
\hline wetness & 0.1511 & 0.1973 & 0.3283 & 0.3407 & -0.7117 & -0.4559 \\
\hline
\end{tabular}

Table 3. Pairwise comparison matrix

\begin{tabular}{|c|c|c|c|c|c|}
\hline \multirow{2}{*}{ Criteria } & \multicolumn{5}{|c|}{ Pairwise comparison matrix } \\
\cline { 2 - 6 } & $\begin{array}{c}\text { Nutrient } \\
\text { availability }\end{array}$ & Slope & Wetness factor & Rainfall & Elevation \\
\hline Nutrient availability & 1 & 2 & 2 & 3 & 3 \\
\hline Slope & $1 / 2$ & 1 & 2 & 3 & 6 \\
\hline Wetness factor & $1 / 2$ & $1 / 2$ & 1 & 2 & 2 \\
\hline Rainfall & $1 / 3$ & $1 / 3$ & $1 / 2$ & 1 & 1 \\
\hline Elevation & $1 / 3$ & $1 / 6$ & $1 / 4$ & & 4 \\
\hline
\end{tabular}

Table 4. Normalized matrix of various thematic layer with weight

\begin{tabular}{|l|c|c|c|c|c|c|c|}
\hline \multirow{2}{*}{ Criteria } & \multicolumn{7}{|c|}{ Normalized pairwise comparison matrix } \\
\cline { 2 - 8 } & $\begin{array}{c}\text { Nutrient } \\
\text { availability }\end{array}$ & Slope & $\begin{array}{c}\text { Wetness } \\
\text { factor }\end{array}$ & Rainfall & Elevation & $\begin{array}{c}\text { Priority } \\
\text { vector }\end{array}$ & Weight (\%) \\
\hline $\begin{array}{l}\text { Nutrient } \\
\text { availability }\end{array}$ & 0.375 & 0.5 & 0.3478 & 0.3158 & 0.1875 & 0.35 & 35 \\
\hline Slope & 0.1875 & 0.25 & 0.3478 & 0.3158 & 0.375 & 0.296 & 29.6 \\
\hline Wetness factor & 0.1875 & 0.125 & 0.1739 & 0.2105 & 0.25 & 0.187 & 18.7 \\
\hline Rainfall & 0.125 & 0.08333 & 0.0869 & 0.1026 & 0.125 & 0.104 & 10.4 \\
\hline Elevation & 0.125 & 0.04666 & 0.0435 & 0.0513 & 0.0675 & 0.063 & 6.3 \\
\hline \multicolumn{7}{|c|}{ Consistency Ratio (CR) $=4.2 \%$ Principal Eigen Value $=5.19$} & \\
\hline
\end{tabular}


Table 5. Weight matrix for parameters for agroforestry suitability mapping

\begin{tabular}{|c|c|c|c|c|}
\hline Agroforestry factor & Weight & Value/Description & Ranks & Suitability \\
\hline Nutrient availability & 35 & $\begin{array}{l}\text { Three categories based on } \\
\text { weighted average output }\end{array}$ & $\begin{array}{l}3 \\
2 \\
1\end{array}$ & $\begin{array}{l}\text { High } \\
\text { Medium } \\
\text { Low }\end{array}$ \\
\hline Slope & 29.6 & $\begin{array}{c}<5 \\
5-15 \\
>15\end{array}$ & $\begin{array}{l}3 \\
2 \\
1\end{array}$ & $\begin{array}{l}\text { High } \\
\text { Medium } \\
\text { Low }\end{array}$ \\
\hline Wetness factor & 18.7 & $\begin{array}{l}\text { Three categories based on } \\
\text { weighted average output }\end{array}$ & $\begin{array}{l}1 \\
2 \\
3\end{array}$ & $\begin{array}{l}\text { Low } \\
\text { Medium } \\
\text { High }\end{array}$ \\
\hline Rainfall & 10.4 & $\begin{array}{c}<965 \mathrm{~mm} \\
965-985 \mathrm{~mm} \\
>985 \mathrm{~mm}\end{array}$ & $\begin{array}{l}1 \\
2 \\
3\end{array}$ & $\begin{array}{l}\text { Low } \\
\text { Medium } \\
\text { High }\end{array}$ \\
\hline Elevation & 6.3 & $\begin{array}{l}<400 \text { meter } \\
400-600 \text { meter } \\
>600 \text { meter }\end{array}$ & $\begin{array}{l}3 \\
2 \\
1\end{array}$ & $\begin{array}{l}\text { High } \\
\text { Medium } \\
\text { Low }\end{array}$ \\
\hline
\end{tabular}

Table 6. Weight matrix for parameters and ranking for nutrient availability mapping

\begin{tabular}{|c|c|c|c|c|}
\hline Nutrient factor & Weight factor & Value/Description & Ranks & Suitability \\
\hline Nitrogen & 1 & $\begin{array}{c}>560 \mathrm{~kg} / \mathrm{ha} \\
560-280 \mathrm{~kg} / \mathrm{ha} \\
<280 \mathrm{~kg} / \mathrm{ha}\end{array}$ & $\begin{array}{l}3 \\
2 \\
1\end{array}$ & $\begin{array}{l}\text { High } \\
\text { Medium } \\
\text { Low }\end{array}$ \\
\hline Phosphorus & 1 & $\begin{array}{c}>25 \mathrm{~kg} / \mathrm{ha} \\
25-10 \mathrm{~kg} / \mathrm{ha} \\
<10 \mathrm{~kg} / \mathrm{ha}\end{array}$ & $\begin{array}{l}3 \\
2 \\
1\end{array}$ & $\begin{array}{l}\text { High } \\
\text { Medium } \\
\text { Low }\end{array}$ \\
\hline Potassium & 1 & $\begin{array}{c}>280 \mathrm{~kg} / \mathrm{ha} \\
280-108 \mathrm{~kg} / \mathrm{ha} \\
<108 \mathrm{~kg} / \mathrm{ha}\end{array}$ & $\begin{array}{l}3 \\
2 \\
1\end{array}$ & $\begin{array}{l}\text { High } \\
\text { Medium } \\
\text { Low }\end{array}$ \\
\hline Organic carbon $(\%)$ & 1 & $\begin{array}{c}>0.75 \\
0.75-.50 \\
<0.50 \\
\end{array}$ & $\begin{array}{l}3 \\
2 \\
1\end{array}$ & $\begin{array}{l}\text { High } \\
\text { Medium } \\
\text { Low }\end{array}$ \\
\hline $\mathrm{pH}$ & 1 & $\begin{array}{c}6.6-7.3 \\
7.4-8.4,6.5-5.6 \\
<5.5,>8.5 \\
\end{array}$ & $\begin{array}{l}3 \\
2 \\
1\end{array}$ & $\begin{array}{l}\text { High } \\
\text { Medium } \\
\text { Low }\end{array}$ \\
\hline Sulfur & 1 & $\begin{array}{c}>20 \mathrm{mg} / \mathrm{kg} \\
20-10 \mathrm{mg} / \mathrm{kg} \\
<10 \mathrm{mg} / \mathrm{kg}\end{array}$ & $\begin{array}{l}3 \\
2 \\
1\end{array}$ & $\begin{array}{l}\text { High } \\
\text { Medium } \\
\text { Low }\end{array}$ \\
\hline
\end{tabular}

\subsection{Agroforestry suitability analysis}

The geospatial modeling was executed by integrating all thematic layers with their calculated weightage (Table 5) using weighted overlay technique. Agroforestry suitability surface grid $(1 \mathrm{~km} \mathrm{X} 1 \mathrm{~km})$ was finally obtained based on their surface values they are classified into 3 agroforestry suitability classes (high, medium and low).

\section{Results}

\subsection{Nutrient availability mapping}

Canopy development in crops is directly affected by nutrient availability (Hartz-Rubin \& DeLucia, 2001). The soil nutrient parameter which is essential for plant growth such as nitrogen, phosphorus, potassium, sulpher, $\mathrm{pH}$ and organic carbon was utilized for the production of nutrient availability map. Layers of soil nutrient are important which 

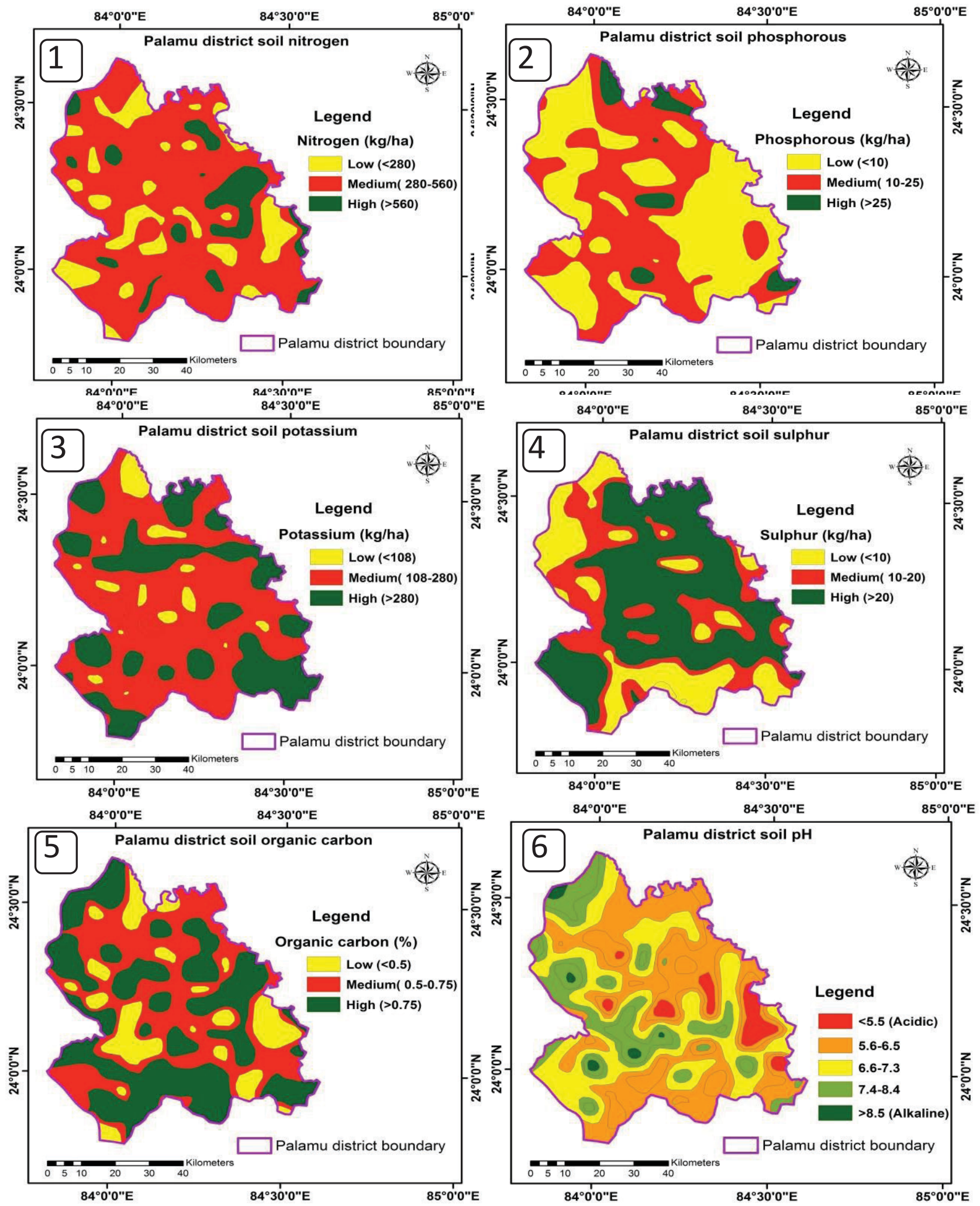

Figure 3. Soil map: 1 - Nitrogen; 2 - Phosphorous; 3 - Potassium; 4 - Sulphur; 5. Organic carbon; 6 - pH 
manifest soil fertility of the existing land towards various agroforestry plant needed for its growth and its metabolic activity. To generate the nutrient availability map (Fig. 4) equal weights (Table 6) was assigned to all soil nutrient layers because of its importance towards plant growth. Similar study has been carried out by Yedage et al. (2013) for land suitability mapping for agroforestry crop.

A grid of $1 \mathrm{~km} \mathrm{x} 1 \mathrm{~km}$ was created over the Palamu district in the form of shape file. The final nutrient availability map (Fig. 5) was generated based on grid is highly useful themes for agriculture, forestry and agroforestry related management and planning.

\subsection{Agroforestry suitability mapping}

The thematic layers which is important for the growth of various agroforestry plant such as nutrient availability, slope, wetness, rainfall and elevation was brought for GIS integration and weight are assigned to each thematic layer based on the Table 2 which was calculated by using pairwise comparisons (Saaty et al., 1980) a widely acceptable statistical tool in GIS (Sarkar et al., 2014) for agroforestry suitability mapping. The agroforestry suitability map generated is shown in Figure 6. The result exhibit 2083, 744 and 507 of the study area (open land) grid are as high, medium and low respectively suitable for agroforestry practices (Table 7). The ongoing agroforestry projects can be diverted in these identified areas of high suitability land grid for optimum output which will certainly fetch the outstanding result.

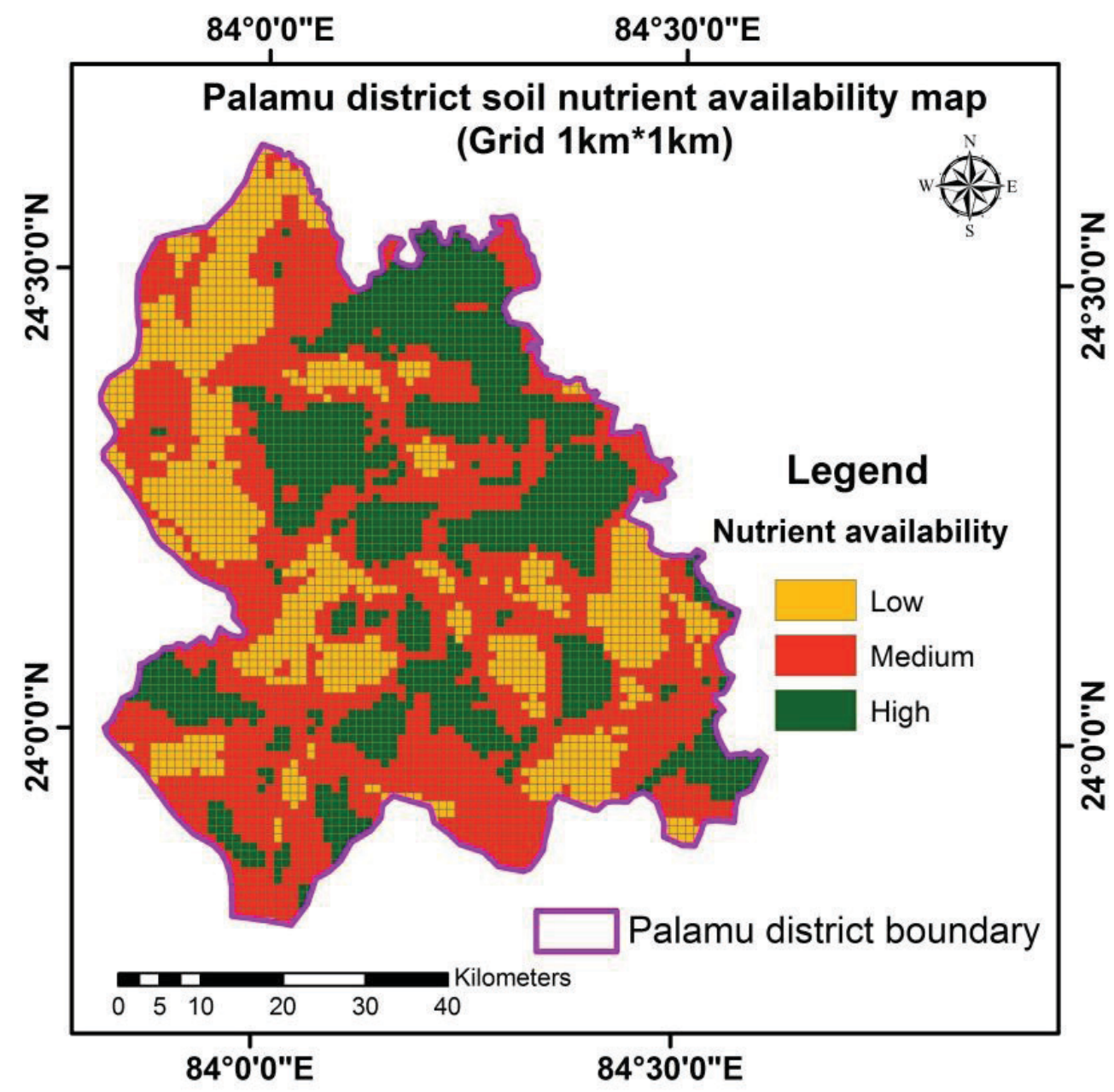

Figure 4. Nutrient availability map 
Table 7. Agroforestry suitability with LULC grids (in open area) of study area with area statistics

\begin{tabular}{|c|c|c|c|}
\hline & & No. of grid & Percentage \\
\hline \multirow{3}{*}{ 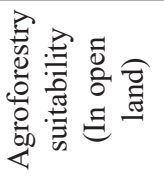 } & High & 2083 & 43.08 \\
\hline & Medium & 744 & 15.39 \\
\hline & Low & 507 & 10.49 \\
\hline \multirow{3}{*}{ 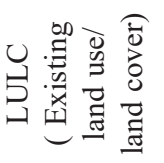 } & Settlement & 10 & 0.21 \\
\hline & Water & 11 & 0.23 \\
\hline & Vegetation & 1480 & 30.61 \\
\hline
\end{tabular}
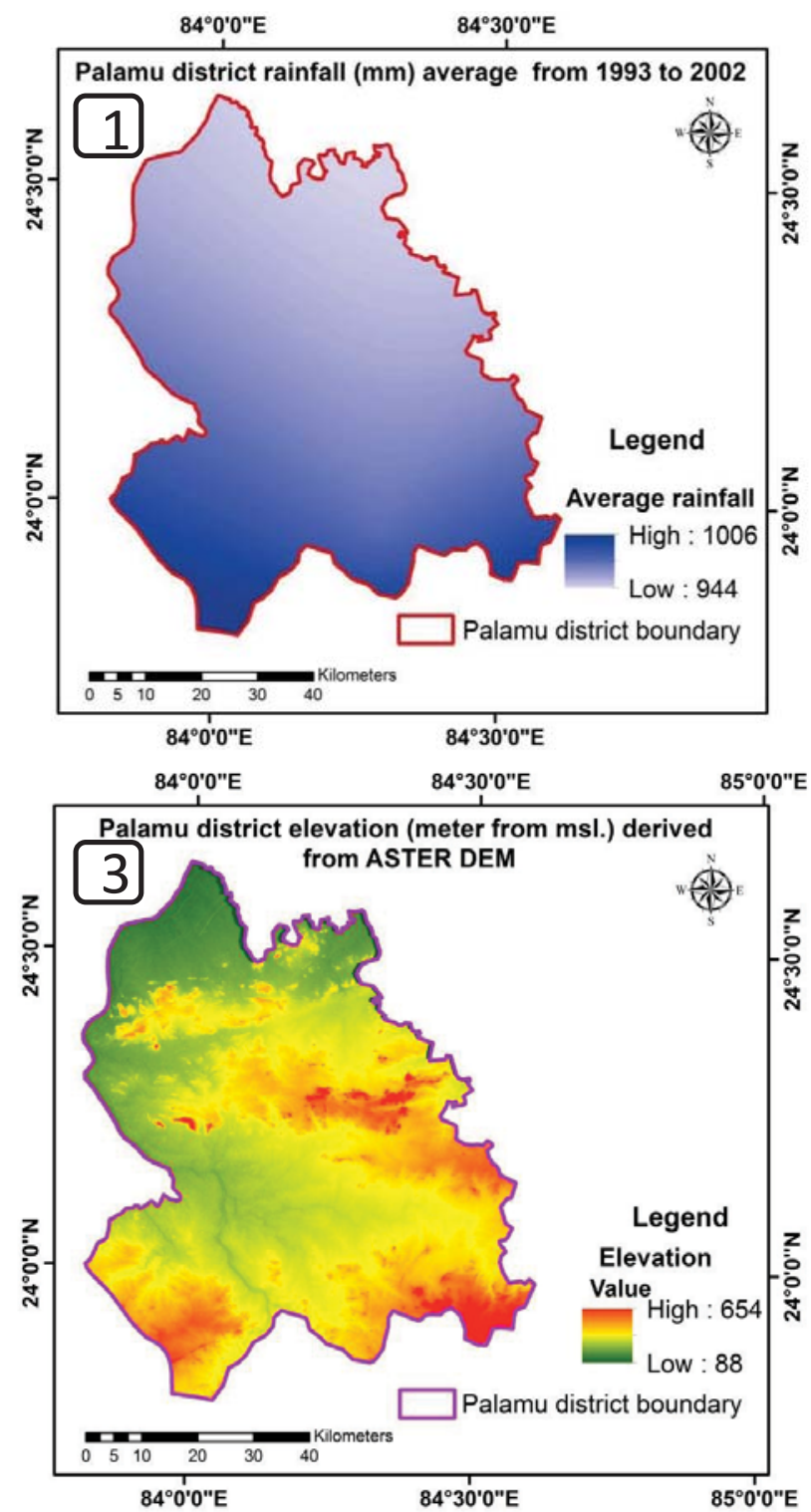

\subsection{Watershed, drainage and poverty} grid based spatial evaluation of land towards agroforestry suitability

The emphasis of the study was to bring the outcomes to the end users, who are local citizen/villagers of this district. Watershed is being the natural boundary is best suited to tap the local resources in conjunction with the rainwater harvest for conservation and planning. Watersheds and drainage were delineated using DEM in the part of study area to understand the proximity of land suitability towards agroforestry. It was found approximately $60 \%$ of the land
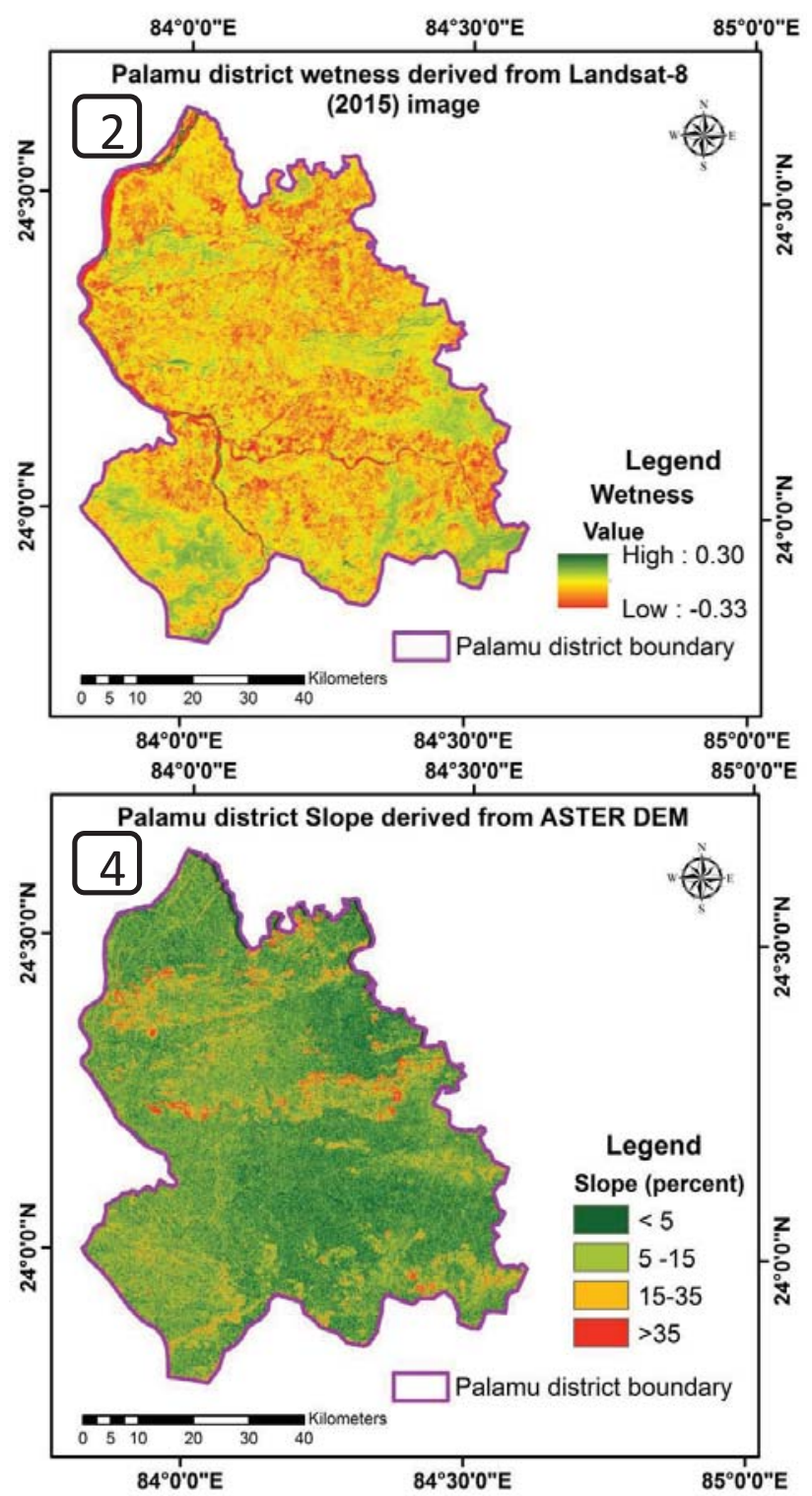

Figure 5. Agroforestry suitability layers: 1 - Rainfall; 2 - Wetness; 3 - Elevation; 4 - Slope 


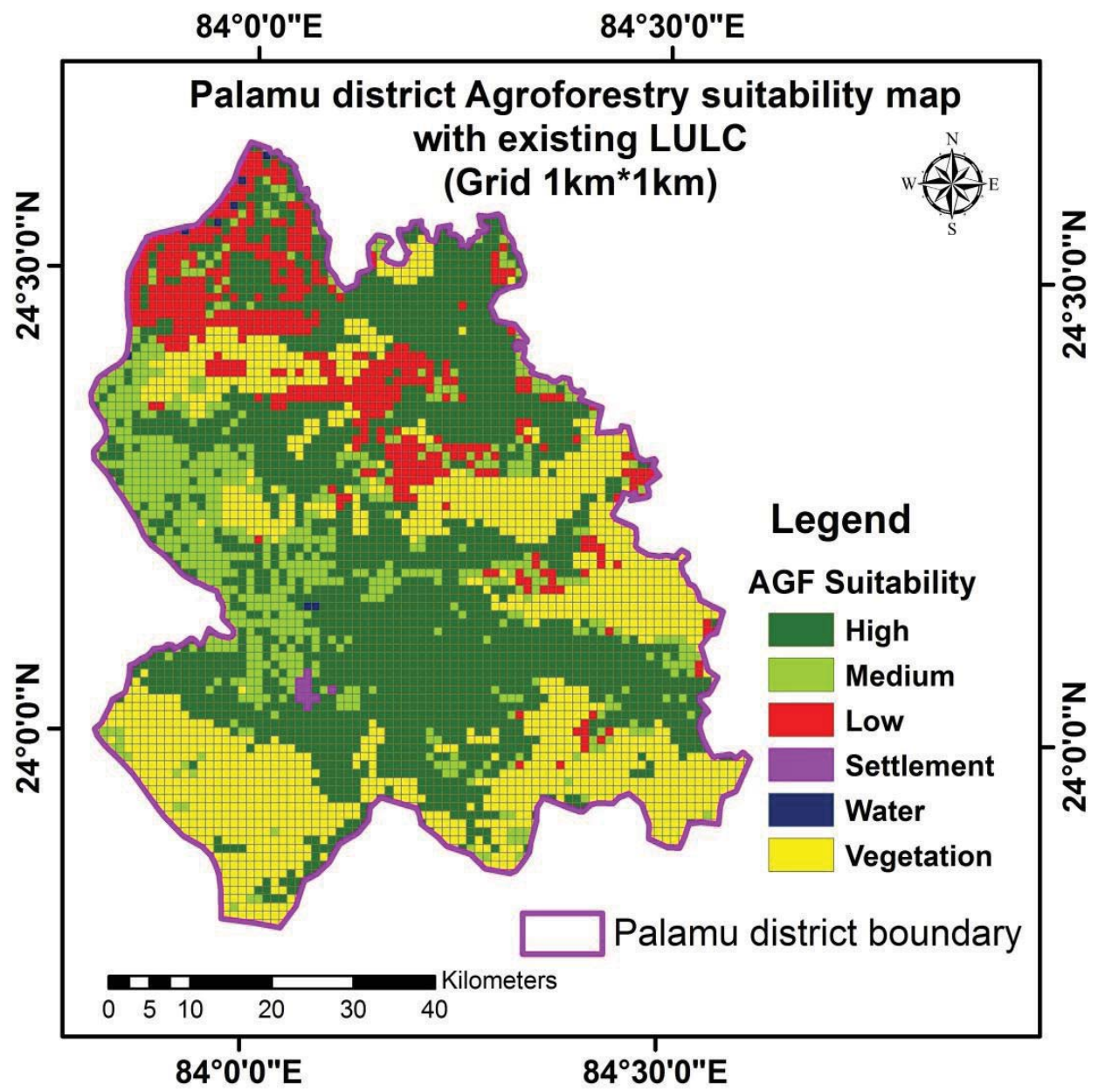

Figure 6. Agroforestry suitability map with existing LULC

of this watershed area consist of high agroforestry suitability grid. Agroforestry potential land and its proximity to drainage show very strong correlation. Approximately $70 \%$ of agroforestry suitable land shows proximity with drainage pattern (Fig. 8) provides a good opportunity to explore agroforestry practices in conjugation with soil and water conservation practices in the rain fed area. Soil and water conservation structure should be made in flow of seasonal rivers to tap the monsoon rain water which will not only enhance soil moisture after monsoon season but also provide the opportunity to harness agroforestry crops for longer duration.

The poverty map (Fig. 7) was generated using visual interpretation of grid map produced by Bhandari and Chakraborty (2014) was further analyzed with respect to agroforestry map which shows the high poverty grid roughly consist more than $80 \%$ of the high agroforestry suitable area can be utilized by the villagers to harness the opportunity to practice agroforestry. Finally we can conclude here that the poor inhabitant of these area need adequate funds/technology by Government/NGO' to carry out watershed based agroforestry projects including soil and water conservation measures in high agroforestry suitable land grid. This will provide several benefit to the local people including enhancing the small scale household income and improving the livelihood (El-Lakany, 2004; Mbwambo et al., 2013). Thus FAO has rightly stated agroforestry has the potential to reduce poverty (http://www.fao.org/forestry/agroforestry/90010/ en/)

\subsection{Validation of result}

Agroforestry suitability map was validated with reference to Google Earth map and field verification (Fig. 9). These high suitability areas in open space were found covered with least to no vegetation even though it has the capability to exhibit more vegetation due to low slope, high fertility 


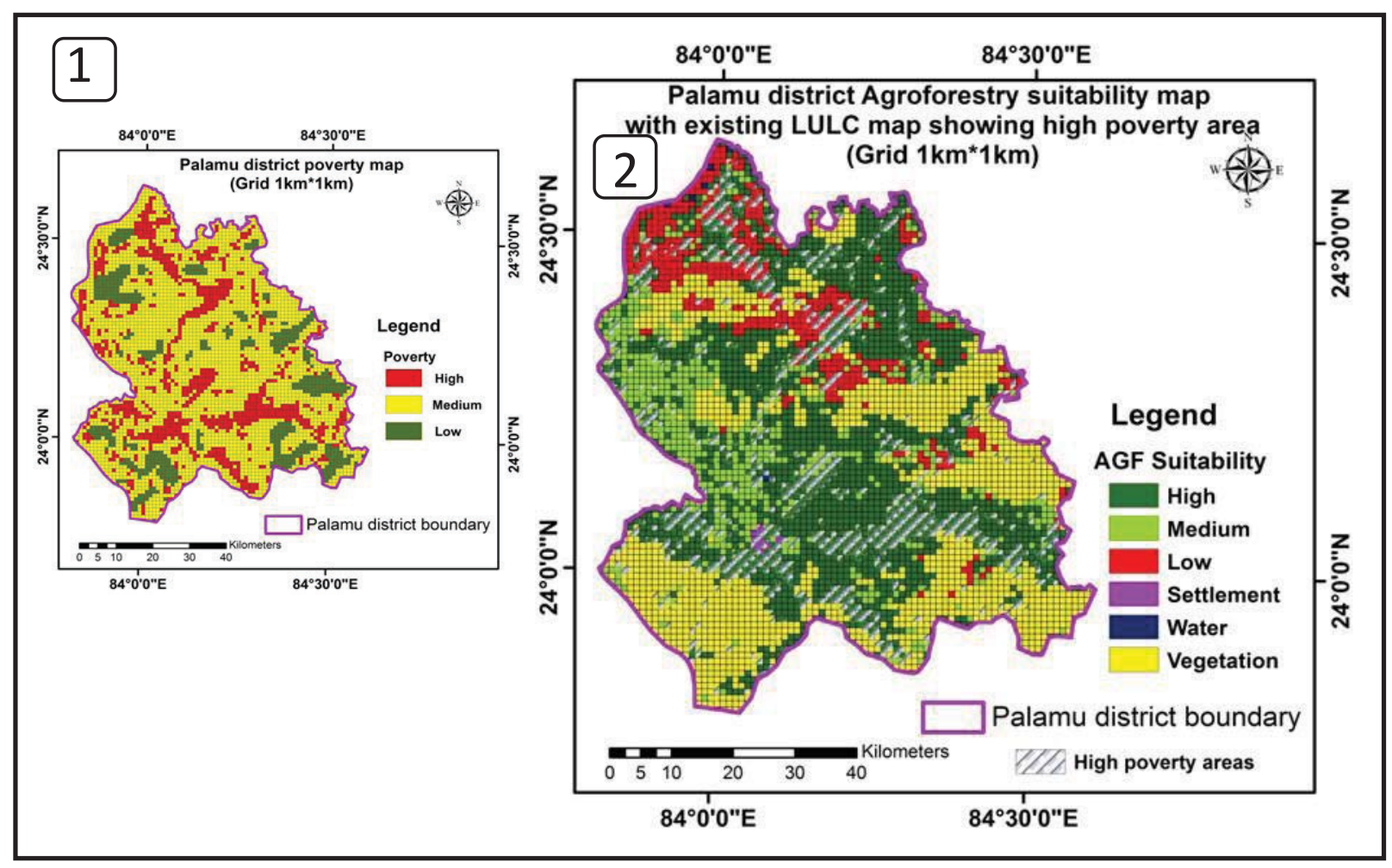

Figure 7. Correlation between poverty and agroforestry suitability: 1 - Poverty map; 2 - Agroforestry suitability map overlaid with high poverty grid

status and has the capacity to retain moisture if it is scientifically utilized.

\subsection{Agroforestry suitability rating}

High priority areas: These areas exhibit high soil nutrient, adequate wetness with gentle slope and low elevation which provide high favorable condition for the agroforestry plant/ crop growth. It comprises of 2083 grids. These areas are highly fertile and best suitable for agri-silvi-horticulture system. Agriculture crop specially paddy crops in low land (locally called don) areas can be suitably harvested due adequate availability of water and moisture during monsoon season whereas after monsoon season these area can have enormous potential for horticulture crop as these area can retain soil moisture if skillfully managed even after monsoon season. Large chunks of uplands (locally called tar) area with suitable climate and high nutrient status that offers immense potential for diversification under horticultural crops (fruit crops such as Mango, Guava, Lemon, Papaya and Jackfruit etc. whereas vegetables such as potato, cauliflower, brinjal, tomato, cabbage, pea etc. Considering the agroforestry suitability potential and availability of vast area a well thought out plan of action needs to be formulated and implemented to realize the potential of horticulture in these areas. The endogenous tree species such as Sisam (Dalbergia sissoo), Ber (Zizyphus mauritiana) tree, Palas (Butea monosperma), Kusum (Schleichera oleosa) Asan (Terminalia tomentosa), Arjun (Terminalia arjuna) can be planted.

Soil and water conservation management (mechanical or structural measures) such as small check dam construction, water harvesting structure and ridge raised along the slope can help to conserve every drop of rainwater in the area. This will secure soil moisture throughout the year and also reduce soil erosion due to control on surface runoff velocity will provide more intensive opportunity to harness the agroforestry technology.

Medium priority areas: These areas mostly exhibit high to medium soil nutrient, moderate wetness, moderate rainfall with low to moderate slope and low to medium elevation provided average favorable condition towards agroforestry plant/ crop growth. It comprises of 744 grids. These areas exhibit average to low soil fertility, inadequate soil moisture except during rainy seasons and sign of soil erosion is common due to average slope. There is a need to adopt soil and water conservation measure intensively to make the land more feasible. These areas can be used for silvi-pastural system and plantation of species such as 


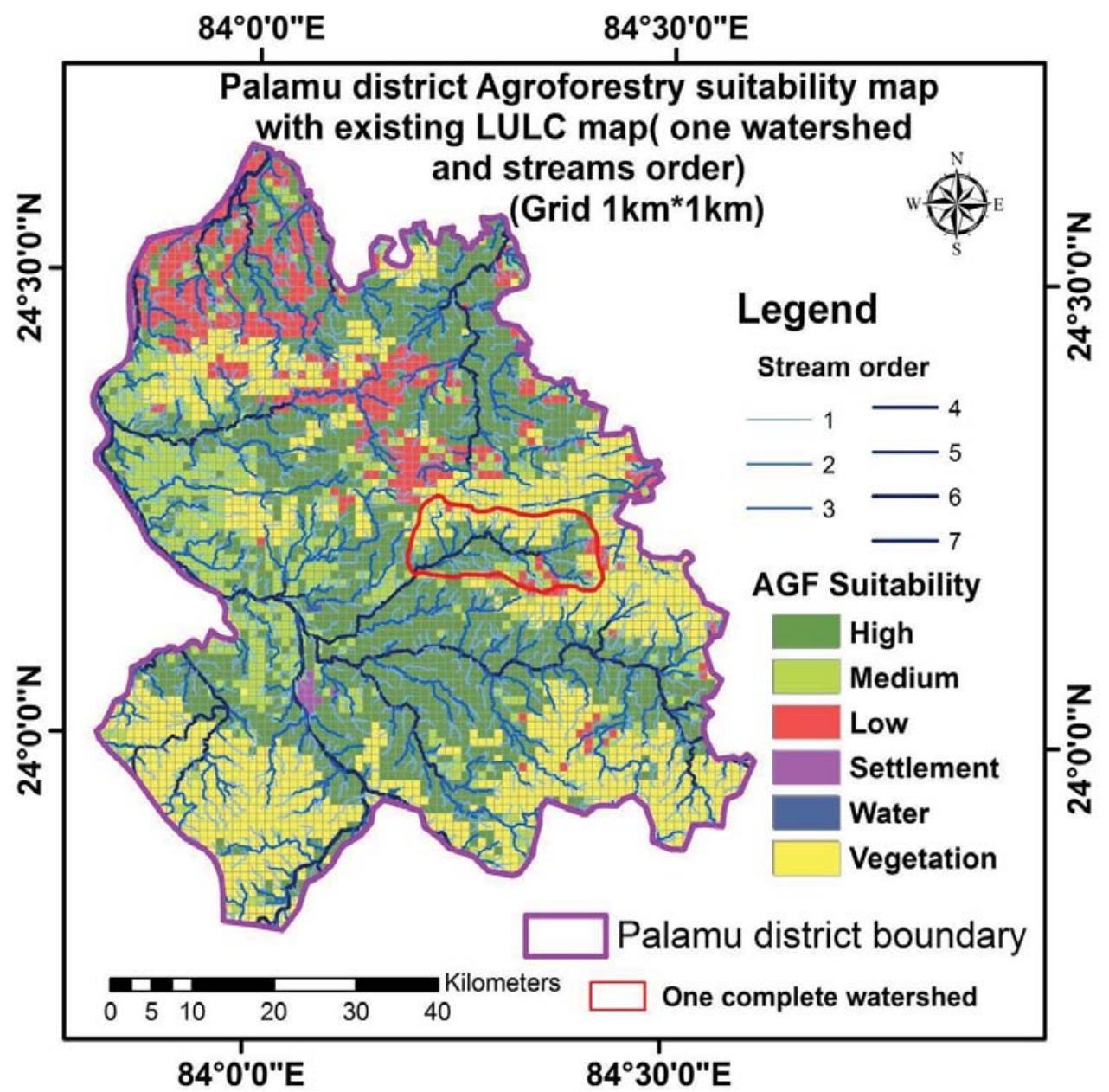

Figure 8 . Agroforestry suitability map overlaid with drainage and one watershed

Acacia nilotica, Zizyphus mauritiana, Grewia optiva (beul) tree with soil binder grasses (Saccharum munja) is likely to produce the good results.

Low priority areas: These areas exhibit low soil nutrient, wetness, rainfall, steep slope and high elevation which provides the least favorable condition for the plant growth. It accounted for 507 grids and it mostly comprises of highly exposed rocks with low soil depth with eroded sloppy land. These areas strongly exibit poor fertility needed to be treated with good organic matter by farm yard manure (FYM) and green manure. Soil moisture is relatively very low and sign of high soil erosion in this area due to steep slope thus mandatory for soil and water conservation practices to make it favorable to plant growth. These area can be used for dry land farming after the improvement. The trees Acacia nilotica (kikar), Zizyphus mauritiana (ber), Azadirachta indica(neem) crops suitable can be grown in this area. Munj (Saccharum munja) and kas (Saccharum spontaneum) grass can be used in sloppy area to reduce soil erosion.

\section{Discussion}

To enhance the livelihood of the poor people suffering from starvation, food scarcity there is a strong need to adopt various agroforestry practices in the identified potential sites based on scientific evaluation procedure of land suitability which was previously not been attempted need policy intervention. The forester, agriculturalist, agro-forester however need to use these technologies extensively (Ellis et al., 2000). Following agroforestry practices (Figure 10 as an example) with adequate soil and water conservation measures can be adopted will be highly useful if implemented in study area seeing the fitness of site such as it's topography, soil moisture condition and soil erosion extent. 


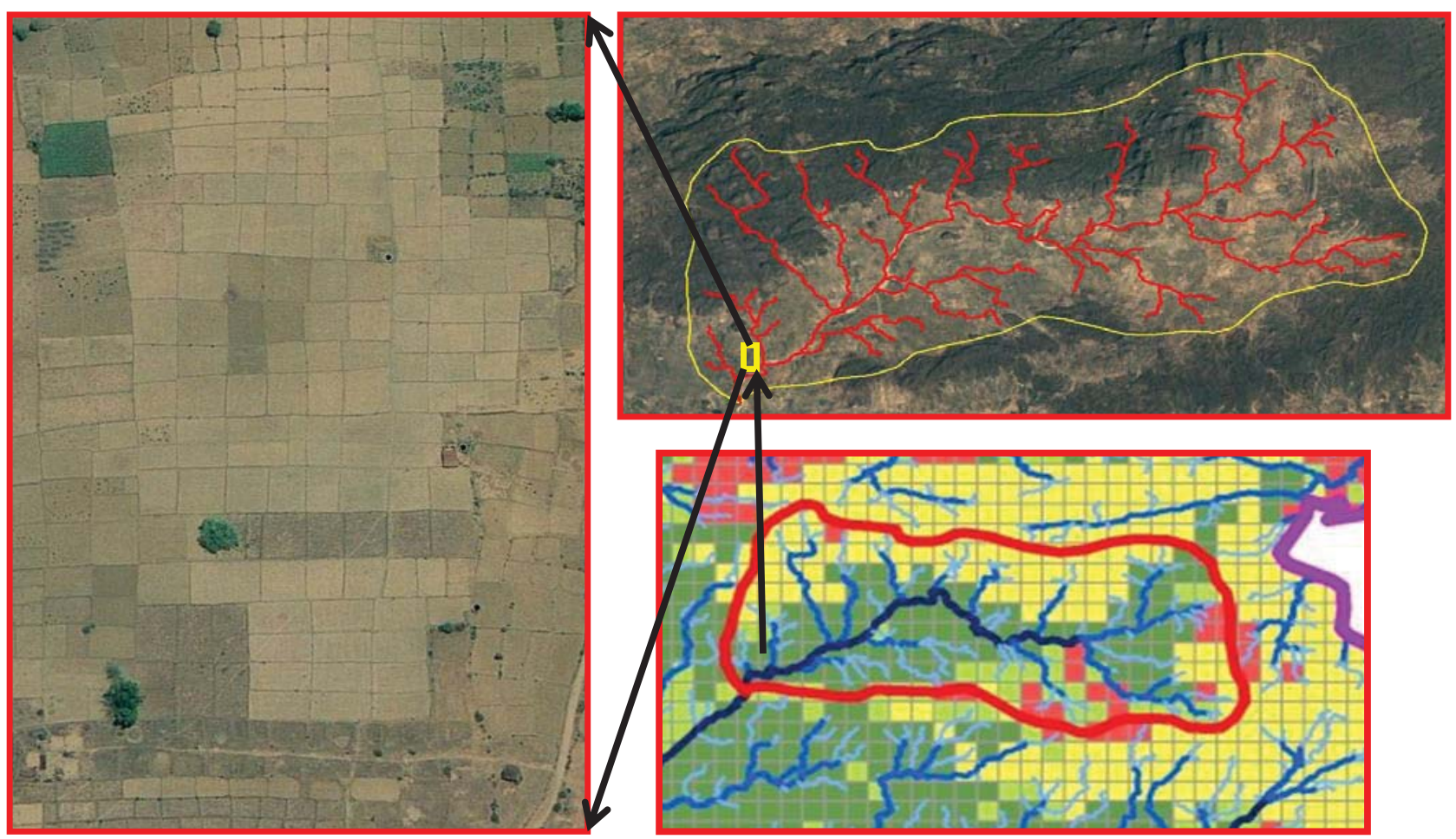

Figure 9. Cross validation of watershed based agroforestry suitability

Kumar (2014) has presented one paper in world agroforestry forum in which he has given the emphasis for growing silk host trees such as Asan (Terminalia tomentosa), Arjun (Terminalia arjuna) and Shorea robusta trees and on Lagerstroemia parviflora and Zizyphus mauritiana which is native to the state of Jharkhand and has the potential to increase the income of small and marginal farmers.

The agroforestry practice with tree species Palas (Butea monosperma), Kusum (Schleichera oleosa) and Zizyphus mauritiana (Kumar, 2014) can be utilized for collecting lac (a natural resin) secreted by an insect, Kerrialacca (Kerr.) also have the capacity to grow in dry climatic condition will further boost the livelihood to the villagers if included in the agroforestry practice. These species are native to these study area and best suited for Palamu district.

Soil fertility and moisture is always taken in account while practicing agroforestry thus role of leguminous tree has great importance in soil improvement has the capacity to add nitrogen to the soil (Nair, 1984). Tree species such as Delbergia sissoo can be included in agroforestry system because it can be grown in drought prone soils and tolerate extremes of temperature $\left(>50^{\circ} \mathrm{C}\right)$ and provides tannins, gums, timber, fuel, fodder and medicine will further boost the livelihood of the inhabitant.

The horticulture crop such as papaya, mango, guava, lemon and jack fruits tree species can be brought into
Agroforestry practices. Mukesh (2012) has cultivated and evaluated the income generated from one acre of land by growing papaya. The study reveals that a farmer can earn a profit of at least 1/10 million Indian Rupees (roughly 1500 USD) per season from one acre of land.

Sukhomajri project experience: Late P.R. Mishra, A leading soil conservationist at the Soil and Water Training Institute, Chandigarh, India. When Mishra stated working on the Sukhomajri project in the early 1970s, the village was suffering from ecological problems. The land was with poor vegetation it could sustain only poor crops. Soil erosion caused heavy runoff and soil loss. Mishra's intervention was intended to change all this. Sukhomajri has forest wealth estimated at approximately of Rs 90 crore. The transformation of Sukhomajri from a barren land/ wasteland into a green belt was due to a watershed based soil and water conservation model concept of sustainable development called the Chakriya Vikas Pranali (CVP) that was developed by Mishra himself (http://www.rainwaterharvesting.org/People/RuralJY_westhiml.htm).

Palamu village experience: Chakriya Vikas Pranali (Society of Hill Resource Management School) is a NGO of Palamu, Jharkhand, India established by Sri P.R. Mishra. They work in Palamu remote village has several success stories introduced by "Mishra model" by implementing watershed based soil and water conservation model con- 


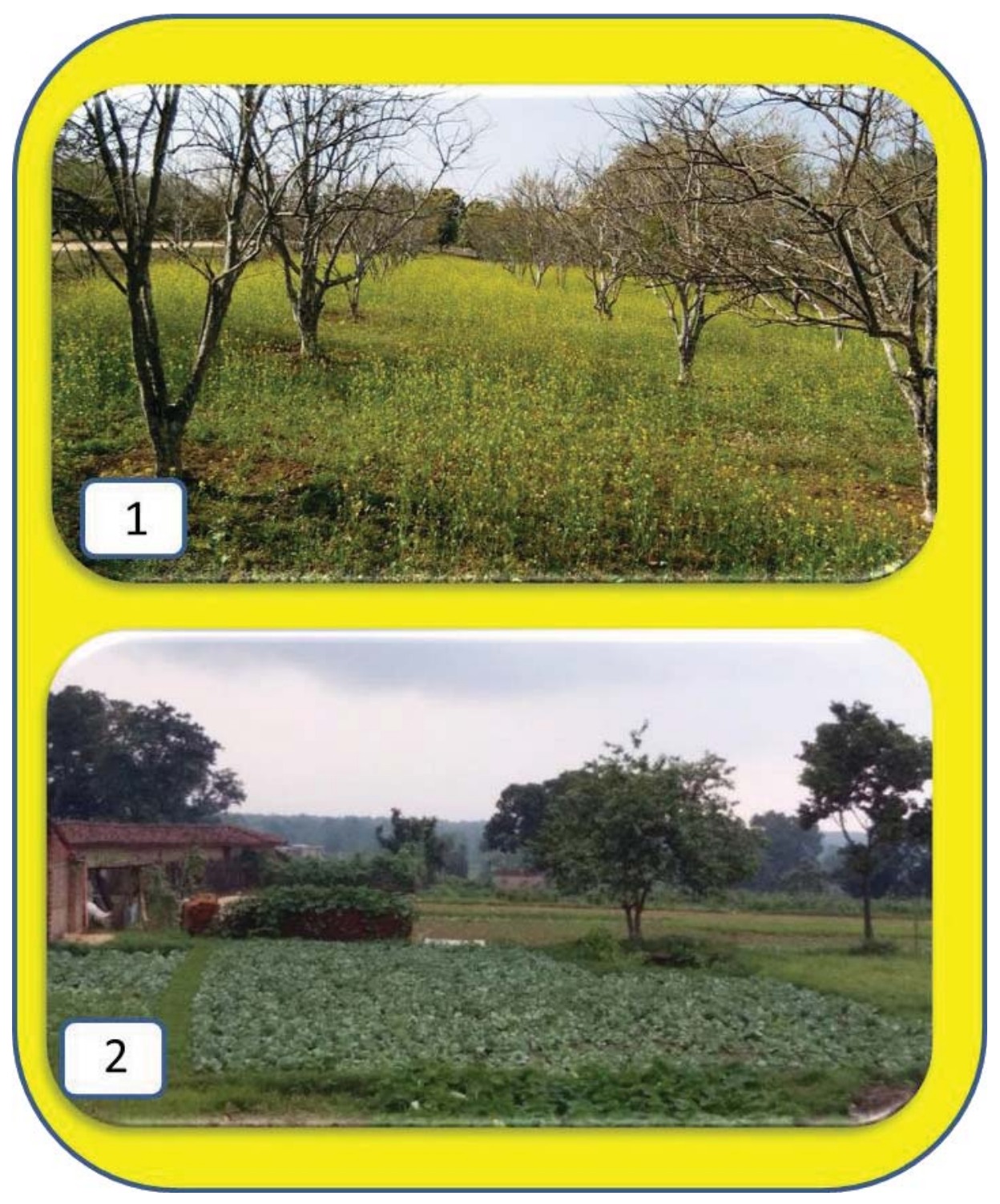

Figure 10. Agroforestry practices: 1 - Agrisilviculture; 2 - Homegarden

cept practicing various agroforestry crop in the number of rural villages by sharing of income which enhanced livelihood and reduce poverty of rural people. He has developed a methodology to share the income among the land owner, CVP workers, and village funds. The villager's income and village fund was increased several fold by adopting agroforestry practices. This great success story never got adequate space in print and electronic media. I recall my (first author) field visited to see his work one of the village Bhusaria, Palamu. We got the opportunity to visit the model work done in Busariya village by Sri P.R. Mishra and also talked to him and villagers. Once upon a time the village was suffering with poverty and struggling for live- lihood was modified in self-reliance village. Village fund was increased to several folds. I remember his two reply first one "regarding the suitable tree species for this area" he replied you can grow any tree species in this area second one "regarding how you are generating the funds for villagers" he replied by raising forest trees seedling in nurseries, growing fruit trees such as papaya, guava, lemon etc. and fuel wood trees like Delbergia sisso, Gmelina arborea and several others long duration tree species in waste land. I was delighted by seeing his work. He always worked without fear in all remote "naxal affected area". He was revolutionary, with a very strong willpower, devotion. He implemented his model concept by winning the heart and 
mind of tribal and poor people of village which helped to eradicate poverty and enhanced livelihood among them. $\mathrm{He}$ is no more with us but he will always be in the heart of those people who directly or indirectly were associated with him. My great tribute to him for his novel work. There is a need to replicate such model concept given by him to several other villages. His basic idea of work is to stop/ catch the rainwater where it falls. So based on my field visit, finally i can conclude he evolve a formula by sharing of income, generated by adopting watershed based agroforestry practice with intensive soil and water conservation measures in the waste land.

Kadwanchi watershed project experience (Goswamy, 2017): Soil conservationist Sri Vijay Borade has adopted integrated watershed management approach on Kadwanchi watershed project in Maharashtra's water-stressed Jalna district (India) in five-year-long project between 1996 and 2001 led to an increase in cropped land from 1,365 hectares to 1,517 hectares. Land under perennial irrigation had also increased roughly 3.5 times. Borade also suggested the solution for drought prone area for practicing conservation at micro level and thinking of localized solutions like ridge to valley treatment of watershed, water budgeting and building embankments to reduce soil erosion.

Simon Oraon based environment conservation approach (Dey, 2016): Octogenarian water warrior Simon Oraon, leading a people's movement to save water and forests has deed the great success story in 51 villages of Bero block in Ranchi district of Jharkhand, India. Oraon's hard work towards soil and water conservation, through rainwater harvesting and building check dams on the flow of seasonal rivers started bearing fruit eventually, and Bedo's water level increased drastically. The waste lands turned cultivable, and there was sufficient water to grow more than one crop a year. Today, Bedo has become the agro horticultural hub of Jharkhand. The block produces nearly 20,000 metric tons of vegetables and supplies to various districts in Jharkhand state, besides neighboring states like Bihar, Odisha and West Bengal.

\section{Conclusion}

This research shows that the potentiality of geospatial technology in delineating suitable sites for studying agroforestry practices. The use of ancillary data sets and pooling in GIS domain as thematic layer and its spatial pattern can have enormous scope to map the land for the benefit of the rural people. The advancement in computer science, image processing, and GIS with its various modules/algorithms toward mapping and further facilitate a logical conclusion/ quick decision related to such research problems.

Our study analysis leads a great expectation for the villagers of Palamu district to harness agroforestry prac- tices if it is supported financially along with appropriate technology by Government, NGO/s, World Bank and other international donor. The research findings have greater importance as India has adopted the agroforestry policy. The agroforestry suitability mapping was done based on similar guidelines documented by FAO for land suitability. There is an urgent need to evaluate, analyze and to generate such map from state level to the village level which gives better spatial understanding of land suitability towards agroforestry which is currently not available with the policy makers/decision makers, is a research gap. Our study highlights the honest attempt to fulfill such gap. The watershed based various agroforestry practices with intensive soil and water conservation measures should be adopted by community participation approach for long term gain in potentially suitable sites. Various agroforestry practices must be evaluated carefully before implementing it in the new area. High resolution satellite data with better DEM quality, highly accurate ancillary data sets and various themes will certainly fetch better result up to the village level. We have not utilized soil depth map into our study due it its unavailability is the future research option.

\section{Acknowledgements}

The authors are grateful to the USGS for free download of Landsat and DEM (ASTER) data which was used in the analysis. Required GIS layers were downloaded from DIVA GIS website.

\section{References}

Ahmad, F. \& Goparaju, L., 2016a, Analysis of Urban Sprawl Dynamics Using Geospatial Technology in Ranchi City, Jharkhand, India. J. Environ. Geogr. 9(1-2): 7-13.

Ahmad, F.\& Goparaju, L., 2016b, Urban Forestry: Identification of Suitable sites in Ranchi city, India using Geospatial Technology. Ecological Question 24: 45-57.

Ahmad, F. \& Goparaju, L., 2017a, Spatio-temporal dynamics of mines in Singrauli, India: An analysis using geospatial technology. Journal of Geomatics 11(1): 53-59.

Ahmad F. \& Goparaju L., 2017b, Conservation prioritization and planning of forest land: a reciprocal approach by measuring forest disturbance using geospatial technology. The Ecoscan 10(3\&4) (in press).

Ahmad F., Goparaju L. \& Qayum A., 2017a, Natural Resource Mapping Using Landsat and Lidar towards Identifying Digital Elevation, Digital Surface and Canopy Height Models. Int. J. Environ. Sci. Nat. Res. 2(1): 555580 . 
Ahmad F., Goparaju L. \& Qayum A., 2017b, LULC analysis of urban spaces using Markov chain predictive model at Ranchi in India. Spat. Inf. Res. DOI: 10.1007/ s41324-017-0102-x.

Ahmad F., Goparaju L. \& Qayum A., 2017c, Studying malaria epidemic for vulnerability zones: Multi-criteria approach of geospatial tools. Journal of Geoscience and Environment Protection 5(5) (in press).

Albrecht A. \& Kandji S.T., 2003, Carbon sequestration in tropical agroforestry systems. Agric. Ecosyst. Environ. 99: 15-27.

Alley R., Berntsen T., Bindoff N., Chen Z., Chidthaisong A, Solomon S., Qin D. \& Manning M., 2007, The Physical Science Basis. Contribution of Working Group I to the 4th Assessment Report of the Intergovernmental Panel on Climate Change. Cambridge University Press, Cambridge, UK.

Anderson S.H., Udawatta R.P., Seobi T. \& Garrett H.E., 2009 , Soil water content and infiltration in agroforestry buffer strips. Agrofor Syst. 75: 5-16.

Asbjornsen H., Hernandez-Santana V., Liebman M., Bayala J., Chen J., Helmers M., Ong C. \& Schulte L., 2014, Targeting perennial vegetation in agricultural landscapes for enhancing ecosystem services. Renew Agric. Food Syst. 29: 101-125.

Baig M.H.A., Zhang L., Shuai T. \& Tong Q., 2014, Derivation of a tasselled cap transformation based on Landsat 8 at-satellite reflectance. Remote Sensing Letters 5: 423-431. doi:10.1080/2150704X.2014.915434.

Bhandari L. \& Chakraborty M., 2014, Spatial poverty in Jharkhand. http://www.livemint.com/Specials/bqVly6xj4usB3DiTibS3DK/Spatial-poverty-in-Jharkhand. html) [Accessed on 9th May 2017].

Bijalwan A., Upadhyay A.P. \& Dobriyal M.J.R., 2015, Tree-crop Combinations, Biomass and Carbon Estimation in Conventional Agrisilviculture (Agroforestry) System along Altitude and Aspects in the Hills of Uttarakhand Himalaya, India. Int. J. Curr. Res. Biosci. Plant Biol. 2(6): 214-217.

Das R., 2005, Poverty and Hunger: Causes and Consequences. Published by Sarup and Sons, New Delhi.

Dey S., 2016, Jharkhand's waterman gets Padma Shri for waging war against drought. (http://www.hindustantimes.com/india/jharkhand-s-waterman-getspadma-shri-for-waging-war-against-drought/story7PgYljQmbDBeahSVg4gjrJ.html) [Accessed on 15th May 2017].

El-Lakany H., 2004, Improvement of Rural Livelihoods: the role of Agroforestry, First World Agroforestry Congress held in Florida, USA. http://www.fao.org/ forestry/7459-03b98002736c1812f203700d24b933c91. pdf [Accessed on 9th May 2017].

Ellis E.A., Nair P.K., Linehan P.E., Beck H.W. \& Blanche C.A., 2000, A GIS-based database management ap- plication for agroforestry planning and tree selection. Computers and Electronics in Agriculture 27: 41-55.

FAO, 1976, A framework for Land evaluation. FAO Soils bulletin 32. (https://www.mpl.ird.fr/crea/taller-colom$\mathrm{bia} / \mathrm{FAO} / \mathrm{AGLL} / \mathrm{pdfdocs} /$ framele.pdf) [Accessed on 22nd April 2017].

Franklin S.E., 2001, Remote sensing for sustainable forest management. CRC Press LLC, 2000 N.W. Corporate Blvd., Boca Raton, Florida.

Garrity D., 2006, Science based agroforestry and the achievement of the millennium development goals, [in:] D. Garrity, A. Okono, M. Grayson, S. Parrott (eds), World Agroforestry into the Future. World Agroforestry Centre Nairobi, Kenya: 3-8.

Goswamy S., 2017, To recharge groundwater, give due attention to soil: conservationist Vijay Borade. (http://www.downtoearth.org.in/news/to-rechargegroundwater-give-due-attention-to-soil-conservationist-vijay-borade-57842) [Accessed on 15th May 2017].

Hartz-Rubin J.S., \& DeLucia E.H., 2001, Canopy development of a model herbaceous community exposed to elevated atmospheric $\mathrm{CO}_{2}$ and soil nutrients. Physiologia Plantarum 113(2): 258-266. DOI: 10.1034/j.13993054.2001.1130214.x.

Hernandez G., Trabue S., Sauer T., Pfeiffer R. \& Tyndall J., 2012, Odor mitigation with tree buffers: Swine production case study. Agric. Ecosyst. Environ. 149: 154-163. Indian Water Portal, 2016, (http://www.indiawaterportal. org/met_data/) [Accessed on 10th March 2017].

Jose S., 2012, Agroforestry for conserving and enhancing biodiversity. Agrofor. Syst. 85: 1-8.

Kumar S., 2014, Contribution of Agroforestry based NTFPs as Livelihood options in Rural Areas of Jharkhand State of India. World Congress on Agroforestry PP1.2.25, Delhi.

Mbow C., Noordwijk M.V., Luedeling E., Neufeldt H., Minang P.A. \& Kowero G., 2014, Agroforestry solutions to address food security and climate change challenges in Africa. Curr. Opin. Environ. Sustain. 6: 61-67.

Mbwambo J.S., Saruni P.L. \& Massawe G.S., 2013, Agroforestry as a solution to poverty in rural Tanzania. Lessons from Musoma Rural District, Mara Region, Tanzania. Kivukoni Journal 1(2): 15-30.

McNeely J.A., 2004, Nature vs. nurture: Managing relationships between forests, agroforestry and wild biodiversity. Agrofor. Syst. 61: 155-165.

Mukesh A.S.R.P., 2012, Progressive farmers in Ranchi, Seraikela-Kharsawan sow dwarf Taiwanese variety to reap tall profits. (http://www.telegraphindia.com/1120419/ jsp/jharkhand/story_15391773.jsp\#.WCCW5y197IV) [Accessed on 18th March 2017].

Nair P.K.R., 1984, Soil productivity aspect of agroforestry, [in:] Science and Practice of Agroforestry (ICRAF), no. 
1 / Nairobi (Kenya), International Council for Research in Agroforestry National Agroforestry Policy, 2014, Government of India. (www.nrcaf.res.in/NAF_Policy. pdf) [Accessed on 22nd October 2016].

National Agroforestry Policy, 2014, Government of India. (http://www.indiaenvironmentportal.org.in/files/file/ Agroforestry\%20policy\%202014.pdf) [Accessed on 26th May 2017].

Nguyen Q., Hoang M.H., Oborn I. \& Noordwijk M.V., 2013, Multipurpose agroforestry as a climate change resiliency option for farmers: An example of local adaptation in Vietnam. Climatic Change 117: 241-257.

Pandey D.N., 2005, Multifunctional Agroforestry Systems in India for Livelihoods: Current Knowledge and $\mathrm{Fu}-$ ture Challenges. (http://services.iriskf.org/data/articles/ Document11092005230.3497126.pdf) [Accessed on 7th May 2017].

Qayum A., Arya R., Kumar P. \& Lynn A.M., 2015, Socioeconomic, epidemiological and geographic features based GIS-integrated mapping to identify malarial hotspot. Malaria Journal 14: 192,1-19. doi: 10.1186/ s12936-015-0685-4.

Quli S.M.S., 2001, Agroforestry for NTFPs conservation and economic upliftment of farmers. Indian Forester 127: 1251-1262.

Reisner Y., de Filippi R., Herzo, F. \& Palma J., 2007, Target regions for silvoarable agroforestry in Europe. Ecological Engineering 29: 401-418.

Ritung S., Wahyunto F.A. \& Hidayat H., 2007, Land Suitability Evaluation with a case map of Aceh Barat District. Indonesian Soil Research Institute and World Agroforestry Centre, Bogor, Indonesia.

Saaty T.L., 1980, The Analytic Hierarchy Process. McGraw-Hill International, New York, NY.

Sarkar A., Ghosh A. \& Banik P., 2014, Multi-criteria land evaluation for suitability analysis of wheat: a case study of a watershed in eastern plateau region. India, Geospatial Information Science 17(2): 119-128. doi: 10.1080/10095020.2013.774106.
Schoeneberger M., Bentrup G., De Gooijer H., Soolanayakanahally R., Sauer T., Brandle J., \& Current D., 2012, Branching out: Agroforestry as a climate change mitigation and adaptation tool for agriculture. Journal of Soil and Water Conservation 67(5): 128A-136A. DOI: 10.2489 /jswc.67.5.128A.

Sileshi G., Akinnifesi F.K., Ajayi O.C. \& Place F., 2008, Meta-analysis of maize yield response to planted fallow and green manure legumes in sub-Saharan Africa. Plant and Soil 307: 1-19.

Singh K.M., Meena M.S., Singh R.K.P., Kumar A \& Kumar A., 2012, Rural Poverty in Jharkhand, India: An Empirical Study based on Panel Data. ICAR-RCER, Patna, NCAP, New Delhi. https://mpra.ub.unimuenchen.de/45258/1/MPRA_paper_45258.pdf [Accessed on 7th May 2017].

Thorlakson T., Neufeldt H. \& Dutilleul F.C., 2012, Reducing subsistence farmers' vulnerability to climate change: Evaluating the potential contributions of agroforestry in western Kenya. Agric. Food Secur. 1: 1-13. Verchot L.V., Noordwijk, M.V., Kandji, S., Tomich, T., Ong, C., Albrecht, A., Mackensen, J., Bantilan, C., Anupama, K. \& Palm, C., 2007, Climate change: linking adaptation and mitigation through agroforestry. Mitig Adapt. Strat. Glob. Chang. 12: 901-918. 10.1007/ s11027-007-9105-6.

Watson, R.T., Noble I.R., Bolin B. Ravindranath N.H., Verardo J.D. \& Dokken D.J., 2000, Land Use, Land-Use Change and Forestry, IPCC Special Report. Cambridge Univ. Press, Cambridge.

World Bank, 2016, Jharkhand Poverty, Growth \& Inequality. (http://documents.worldbank.org/curated/ en/767291467992476557/pdf/105854-BRI-P157572PUBLIC-Jharkhand-Proverty.pdf) [Accessed on 7th May 2017].

Yedage A.S., Gavali R.S. \& Jarag A.P., 2013, Land Assessment for Horticulture (Pomegranate) Crop Using GIS and Fuzzy Decision Analysis in the Sangola Taluka of Solapur District. International Journal of Remote Sensing and GIS 2(3):104-113. 